Tomi Apra Santosa ${ }^{1}$ Eria Marina S. ${ }^{2}$
Submitted : $\quad 10 / 12 / 2020$

Reviewed : $15 / 12 / 2020$

Accepted: $17 / 12 / 2020$

Published: 18/12/2020

\section{ANALISIS MASALAH PENDIDIKAN BIOLOGI PADA SEKOLAH MENENGAH PERTAMA DI ERA PANDEMI COVID -19}

\begin{abstract}
Abstrak
Penelitian ini bertujuan untuk mengetahui masalah pendidikan biologi pada sekolah menengah pertama di era pandemi covid-19. Penelitian ini adalah penelitian kualitatif deskriptif. Subjek yang digunakan dalam penelitian ini adalah siswa dan guru. Objek penelitian ini adalah menganalisis masalah siswa dan guru dalam melaksanakan pembelajaran di era pandemi Covid19. Teknik pengumpulan dari berasal dari observasi, wawancara, dan kuisoiner. Teknik menjamin keabsahan data adalah triangulasi. Teknik analisis data adalah teknik analisis model Miles \& Huberman, yaitu reduksi data, penyejian data, dan verifikasi data. Hasil penelitian ini dapat disimpulkan bahwa masalah yang ditemukan di SMP Negeri 17 Kerinci dalam pembelajaran biologi adalah siswa mengalami kesulitan dalam memahami materi yang diterangkan oleh guru dan Kesulitan dalam mengakses jaringan internet.
\end{abstract}

Kata Kunci: Masalah Pendidikan, Pendidikan Biologi, Covid-19

\begin{abstract}
This study aims to find out the problem of biology education in junior high schools in the covid-19 pandemic era. This research is descriptive qualitative research. The subjects used in this study were students and teachers. The object of this research is to analyze the problems of students and teachers in carrying out learning in the COVID-19 pandemic era. The collection techniques come from observations, interviews, and questionnaires. The technique of ensuring the validity of data is triangulation. Data analysis techniques are Miles \& Huberman model analysis techniques, namely data reduction, data analysis, and data verification. The results of this study can be concluded that the problem found in SMP Negeri 17 Kerinci in biology learning is that students have difficulty in understanding the material described by teachers and difficulty in accessing the internet network.
\end{abstract}

Keywords: Education Issues, Biology Education, Covid-19

\footnotetext{
${ }^{1}$ Program Studi Magister Pendidikan Biologi, FMIPA, Universitas Negeri Padang

Alamat email santosatomiapra@gmail.com

${ }^{2}$ Program Studi Magister Pendidikan Biologi, FMIPA, Universitas Negeri Padang

Alamat email eriamarinasepriyani@gmail.com
} 


\section{PENDAHULUAN}

Wabah pandemi COVID -19 memberikan dampak yang cukup besar di berbagai bidang kehidupan masyarakat Indonesia terutama dalam bidang pendidikan (Ahmad, 2020). Virus COVID-19 ini membuat para siswa dan guru harus melakukan sistem pembelajaran dari rumah masing-masing (study from home) (Handarini \& Wulandari, 2020). Masyarakat Indonesia umumnya belum efektif melakukan sistem sekolah dari rumah karena khususnya bagi orang tua yang produktivitas mereka masih sibuk berkerja di luar rumah (Aji, 2020). Pada pendemi COVID-19 mengharuskan semua aktivitas belajar, bekerja, dan beribadah dilakukan di rumah. Akan tetapi, aktivitas belajar dari rumah sangat membutukan kreativitas siswa dalam menggunakan teknologi, misalnya hanphone dan laptop sebagai media pembelajaran. Penguasaan media pembelajaran oleh siswa merupakan salah satu cara perbaikan kualitas pendidikan (Santosa et al., 2020).

Pendidikan memiliki peran yang sangat penting untuk kemajuan suatu bangsa (Raharjo, 2012). Tak hanya itu, pendidikan di masa pandemi COVID-19 tidak menurunkan semangat bagi siswa untuk tetap belajar. Problematika COVID-19 telah merubah sistem pembelajaran yang dahulu dengan tatap muka langsung menjadi sistem pembelajaran daring atau online. Pembelajaran daring adalah pembelajaran dengan memanfaatkan teknologi untuk sarana pembelajaran secara elektronik dari guru kepada siswanya dengan bantuan jaringan internet yang tidak menuntut siswa hadir dalam kelas (Fauziyah, 2020; Agung et al., 2020). Pemerintah menyarankan bahwa sistem pembelajaran daring ini efektif sebagai solusi untuk menghadapi pandemi dalam dunia pendidikan (Dewi, 2020; Sadikin et al., 2020).

Mutu pendidikan telah mengalami tantangan besar dengan munculnya wabah COVID-19 (Cahyani et al., 2020; Fauzi et al., 2020). Jika pemerintah tidak segera menangulangi kasus ini secara terus-menerus sistem pembelajaran tetap menggunakan sistem Pembelajaran Jarak Jauh (PJJ) (Indrawati, 2020). Pembelajaran Jarak Jauh (PJJ) merupakan sistem pembelajaran yang tidak terhubung antara pendidik dengan peserta didik untuk memberikan pembelajaran secara tidak langsung (Sri Yunita Simanjuntak, 2020). Pembelajaran jarak jauh juga dirasakan oleh siswa Sekolah Menengah Pertama (SMP). Mereka belajar dengan memanfaat berbagai macam aplikasi pembelajaran (Maulah,et.al., 2020). Selain itu, sistem pembelajaran tersebut akan mengurangi motivasi siswa dalam belajar terutama pada pelajaran yang bersifat saintis, misalnya biologi.

Pembelajaran biologi merupakan pembelajaran yang terkesan sulit, banyak hafalan serta membutuhkan siswa berpikir kritis (Jayawardana et al., 2020). Biologi merupakan cabang ilmu pengetahuan yang mempelajari seluk beluk tentang makhluk hidup, seperti hewan, manusia, dan tumbuhan. Dalam proses pembelajaran biologi guru menggunakan aplikasi berupa google classroom, edmodo, whatshapp, dan zoom meeting (Supriyatin, 2020). Dengan penggunaan media teknologi tersebut terkesan mengurangi interaksi antara komponen pembelajaran seperti siswa, guru, kepala sekolah, kurikulum, dan lain sebagainya (Saifulloh \& Darwis, 2020).

Penelitian oleh Ruci Pawicara \& Maharani Conilie (2020) bahwa pembelajaran biologi diera pandemi membuat mahasiswa menjadi jenuh dalam belajar. Penelitian oleh Asmuni (2020) bahwa pelaksanaan pembelajaran daring masa pandemi COVID-19 mengalami berbagai macam masalah pada siswa, guru, dan orang tua. Penelitian oleh Dewi (2020) bahwa pembelajaran daring di sekolah dasar dapat berjalan dengan baik. Penelitian ini bertujuan untuk mengetahui masalah pendidikan biologi pada Sekolah Menengah Pertama (SMP) di era pandemi COVID-19.

\section{METODE}

Penelitian ini adalah penelitian kualitatif deskriptif. Penelitian kualitatif adalah penelitian yang bermaksud untuk memahami fenomena tentang apa yang dialami oleh subjek penelitian secara holistik dan dengan cara deskripsi dalam bentuk kata-kata dan bahasa, pada suatu konteks khusus yang alamiah dan dengan memanfaatkan berbagai metode ilmiah (Moleong, 1995). Teknik pengumpulan data adalah observasi, wawancara, dan kusioner. Teknik menjamin keabsahan data menggunakan teknik triangulasi. Triangulasi adalah teknik pemeriksaan keabsahan data yang memanfaatkan sesuatu yang lain di luar data itu untuk keperluan 
pengecekan atau sebagai pembanding terhadap data itu (Moeleong, 2006). Teknik analisis data adalah teknik analisi model Miles \& Huberman berupa reduksi data, penyajian data, dan verifikasi data (Prastowo, 2016).

\section{HASIL DAN PEMBAHASAN}

Pembelajaran merupakan suatu proses untuk meningkatkan kualitas pendidikan. Pembelajaran dapat dilakukan melalui pendidikan formal maupun informal (Emda, 2011). Tujuan dari pembelajaran adalah untuk meningkatkan kualitas kognitif, afektif, serta ketrampilan siswa. Pada era pandemi COVID -19 siswa SMP Negeri 17 kerinci melakukan sistem Pembelajaran Jarak Jauh (JPP) dengan menggunakan pembelajaran daring. Pembelajaran daring adalah suatu sistem pembelajaran yang menggunakan jaringan internet untuk menjangkau suatu kelompok secara luas dan pembelajaran ini juga dapat dilakukan secara gratis dan berbayar (Despa Ayuni, et.al., 2021). Guru SMP Negeri 17 kerinci menggunakan sistem pembelajaran daring dengan menggunakan berbagai macam platform untuk mendukung kegiatan belajar mengajar.

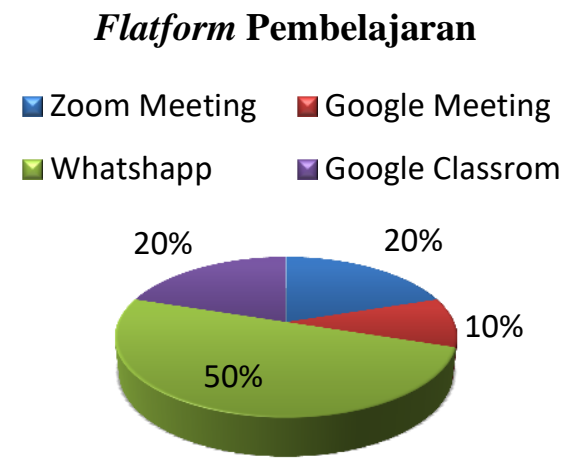

Diagram.1 Flatform Pembelajaran yang Digunakan Guru SMP Negeri 17 Kerinci

Berdasarkan diagram diatas bahwa platform yang banyak digunakan guru biologi SMP Negeri 17 Kerinci adalah whatshapp $50 \%$. Menurut Yulianto, dkk bahwa aplikasi whatsapp 98\% banyak digunakan oleh siswa dan mahasiswa (Yulianto et al., 2020). Aplikasi whatshapp juga memberikan kemudahan bagi guru dalam mengirim materi dan tugas kepada siswa dalam berbagai bentuk, misalnya Microsoft Word, Microsoft Power Point, Link Video, dan lain sebagainya (Rigianti, 2020). Selain itu, aplikasi guru biologi SMP Negeri 17 Kerinci juga menggunakan aplikasi Zoom meting 20\%, Google meeting $20 \%$, dan Google classroom $10 \%$. Dalam proses pembelajaran tidak selalu berjalan dengan baik dalam menggunakan aplikasi tersebut. . 
Tingkat Kesulitan Siswa Dalam Belajar

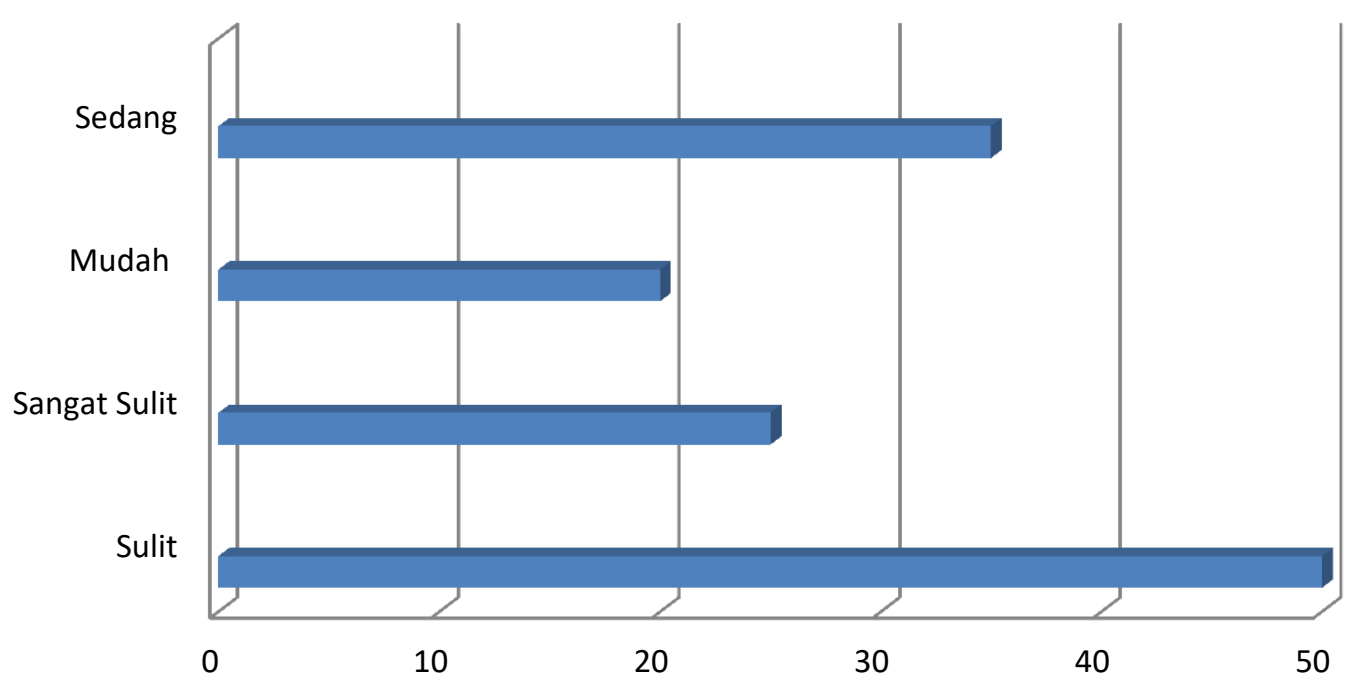

Digaram .2 Tingkat Kusulitan Siswa Dalam belajar

Belajar adalah kewajiban bagi siswa dalam meningkatkan dan mengembangkan potensi yang dimilikinya. Keberhasilan dalam proses belajar mengajar ditentukan oleh guru dalam menggunakan metode pembelajara dan juga ditentukan keingintahuan dan motivasi siswa (Muldayanti, 2013). Berdasarkan diagram di atas Siswa SMP Negeri 17 kerinci mengalami kesulitan dalam melaksanakan pembelajaran secara daring, yakni $50 \%$ siswa menyatakan sulit, $35 \%$ menyatakan sedang, $25 \%$ menyatakan sangat sulit, dan $20 \%$ menyatakan mudah. Dengan alasan konsep dan materi yang disampaikan oleh guru tidak dapat dipahami oleh siswa. Pembelajaran daring tidak efektif digunakan karena di sekolah masih ditemukan guru yang kurang memahami IPTEK (Anggianita \& Rizal, 2020). kesulitan tersebut disebabkan siswa belum bisa mengatur dan menongtrol belajar secara daring dari rumah dan siswa belum mampu memberikan inisiatif untuk diri sendiri (Utami et al., 2020). Materi biologi umumnya berisi materi-materi yang membutuhkan kemampuan berpikir siswa, contoh sistem pencernaan, sistem pernapasan, sistem endokrin, dan sistem syaraf. Dalam materi tersebut siswa harus dapat memahami organ dan fungsi dengan benar dan guru tidak secara langsung memberikan materi kepada siswa tanpa menerangkan secara detail dan rinci.

Dalam pembelajaran biologi siswa SMP Negeri 17 Kerinci mengalami kesulitan jaringan internet dalam menggunakan flatform whatsapp, zoom meeting, google classroom, dan google meeting. Umumnya siswa SMP Negeri 17 Kerinci tinggal di daerah pendesaan yang sulit jangkauan jaringan internet. Jaringan internet merupakan sarana dapat menghubung antara siswa dan guru dalam melakukan proses pembelajaran lewat aplikasi. Maka hal tersebut membuat proses kegiatan belajar mengajar tidak berjalan (Atsani, 2020). Jika kita perhatikan disinilah kelemahan dari sistem pembelajaran daring karena tidak semua siswa bisa menikmatinya. Dalam hal pemerintah dan sekolah harus bisa dengan segera menanggulangi problematika ini.

\section{UCAPAN TERIMA KASIH}

Peneliti mengucapkan terima kasih kepada seluruh civitas SMP Negeri 17 Kerinci kepala sekolah, guru, dan siswa yang telah membantu secara materil maupun imaterial dalam penyelesaikan penelitian ini. 


\section{SIMPULAN}

Dari penelitian diatas dapat disimpulkan bahwa masalah penddikan biologi yang ditemukan di SMP Negeri 17 Kerinci yakni siswa sulit memahami materi pelajaran yang diterangkan oleh guru dan kesulitan mengakses jaringan internet.

\section{DAFTAR PUSTAKA}

Agung, I. G., Wulandari, A., Ngurah, G., \& Agustika, S. (2020). Dramatik Pembelajaran Daring Pada Masa Pandemi Covid-19 ( Studi Pada Persepsi Mahasiswa PGSD Undiksha ). Mimbar PGSD Undiksha, 8(3), 515-526.

Ahmad, I. F. (2020). ALTERNATIVE ASSESSMENT IN DISTANCE LEARNING IN EMERGENCIES SPREAD OF CORONAVIRUS DISEASE ( COVID-19). Jurnal Pedagogik, 07(01), 195-222.

Aji, R. H. S. (2020). Dampak Covid-19 pada Pendidikan di Indonesia : SALAM; Jurnal Sosial \& Budaya Syar-I, 7(5), 395-402. https://doi.org/10.15408/sjsbs.v7i5.15314

Anggianita, S., \& Rizal, M. S. (2020). Persepsi Guru terhadap Pembelajaran Daring di Sekolah Dasar Negeri 013 Kumantan. Journal of Education Research, 1(2), 177-182.

Atsani, L. G. M. Z. (2020). TRANSFORMASI MEDIA PEMBELAJARAN PADA MASA PANDEMI COVID-19. Al-Hikmah: Jurnal Studi Islam, 1, 82-93.

Cahyani, A., Listiana, I. D., Puteri, S., Larasati, D., Islam, U., Sunan, N., Yogyakarta, K., Islam, U., Sunan, N., Yogyakarta, K., Islam, U., Sunan, N., Yogyakarta, K., \& Belajar, M. (2020). Motivasi Belajar Siswa SMA pada Pembelajaran Daring di Masa Pandemi Covid19. IQ (Ilmu Al-Qur'an): Jurnal Pendidikan Islam, 3(01), 123-140.

Despa Ayuni1? , Tria Marini2, Mohammad Fauziddin 3, Y. P. (2021). Jurnal Obsesi : Jurnal Pendidikan Anak Usia Dini Kesiapan Guru TK Menghadapi Pembelajaran Daring Masa Abstrak. Jurnal Obsesi : Jurnal Pendidikan Anak Usia Dini, 5(1), 414-421. https://doi.org/10.31004/obsesi.v5i1.579

Dewi, M. (2020). Analisis Kerja Sama Guru Dengan Orang Tua Dalam Pembelajaran Online Di Era Covid 19 Di MI Azizan Palembang. Jemari: Jurnal Edukasi Madrasah Ibtidaiyah, 2(2), 54-64.

Emda, A. (2011). PEMANFAATAN MEDIA DALAM PEMBELAJARAN BIOLOGI DI SEKOLAH. Jurnal Ilmiah DIDAKTIKA, XII(1), 149-162.

Fauziyah, N. (2020). Dampak Covid-19 Terhadap Efektivitas Pembelajaran Daring Pendidikan Islam. Jurnal Al-Mau'izhoh, 2(2), 1-11.

Handarini, O. I., \& Wulandari, S. S. (2020). Pembelajaran Daring Sebagai Upaya Study From Home ( SFH ) Selama Pandemi Covid 19 Pembelajaran Daring Sebagai Upaya Study From Home ( SFH ) ... .. Jurnal Pendidikan Administrasi Perkantoran (JPAP), 8(1), 496503.

Indrawati, B. (2020). Tantangan Dan Peluang Pendidikan Tinggi. Jurnal Kajian Ilmiah (JKI), $1(1), 39-48$.

Jayawardana, H. B. A., Sugiarti, R., \& Gita, D. W. I. (2020). Inovasi Pembelajaran Biologi di Era Revolusi Industri 4 . 0 (Issue September, pp. 58-66).

Maulah, S., \& , Farikhatun Nurul A, N. R. U. (2020). PERKULIAHAN DARING SEBAGAI SARANA PEMBELAJARAN SELAMA PANDEMI COVID-19. ALVEOLI: Jurnal Pendidikan Biologi, 1(2), 50-61.

Moeleong, L. J. (2006). Penelitian Kualitatif. PT. Remaja Rosdakarya.

Moleong, L. J. (1995). Metode Penelitian Kualitatif. Remaja Rosdakarya.

Muldayanti, N. D. (2013). Jurnal Pendidikan IPA Indonesia. Jurnal Pendidikan IPA Indonesia, $2(1), 12-17$.

Prastowo, A. (2016). Metode Penelitian Kualitatif: Dalam Perspektif Rancangan Penelitian. Ar-Ruzz Media.

Raharjo, S. B. (2012). Jurnal Penelitian dan Evaluasi Pendidikan. Jurnal Penelitian Dan Evaluasi Pendidikan, 16(2), 511-532.

Rigianti, H. A. (2020). KENDALA PEMBELAJARAN DARING GURU SEKOLAH DASAR DI KABUPATEN BANJARNEGARA. Elementary School, 7(2), 297-302. 
Saifulloh, A. M., \& Darwis, M. (2020). DALAM MENINGKATKAN EFEKTIVITAS PROSES BELAJAR MENGAJAR DI MASA PANDEMI COVID-19. Bidayatuna, 3(2), 286-311.

Santosa, T. A., Yulianti, S., Biologi, P. P., \& Padang, U. N. (2020). Pengaruh Pemberian Kuis Terhadap Peningkatan Motivasi Belajar Biologi Siswa di SMA Negeri 7 Kerinci. Science Education and Application Journal (SEAJ, 2(2), 79-87.

Sri Yunita Simanjuntak, K. (2020). Respon Pendidikan Dasar Terhadap Kebijakan Pembelajaran Jarak Jauh Selama Pandemi Covid-19 di Jawa Tengah. Jurnal Ilmiah Wahana Pendidikan, 6(3), 308-316. https://doi.org/10.5281/zenodo.3960169

Supriyatin, T. (2020). Analisis Pembelajaran Filsafat MIPA Berbasis Daring pada Mahasiswa Pendidikan Biologi di Era Pandemi Covid-19 yang digunakan oleh guru . Titin Supriyatin, 1(1), 18-21.

Utami, Y. P., Alan, D., Cahyono, D., \& Indonesia, U. T. (2020). STUDY AT HOME: ANALISIS KESULITAN BELAJAR. Jurnal Ilmiah Matematika Realistik (JI-MR) Vol., $1(1), 20-26$.

Yulianto, E., Cahyani, P. D., \& Silvianita, S. (2020). Perbandingan Kehadiran Sosial dalam Pembelajaran Daring Menggunakan Whatsapp group dan Webinar Zoom Berdasarkan Sudut Pandang Pembelajar Pada Masa Pandemic COVID-19. Jurnal Riset Teknologi Dan Inovasi Pendidikan (JARTIKA), 3(2), 331-341. 